\title{
Solid waste management practices in Zimbabwe: A case study of one secondary school
}

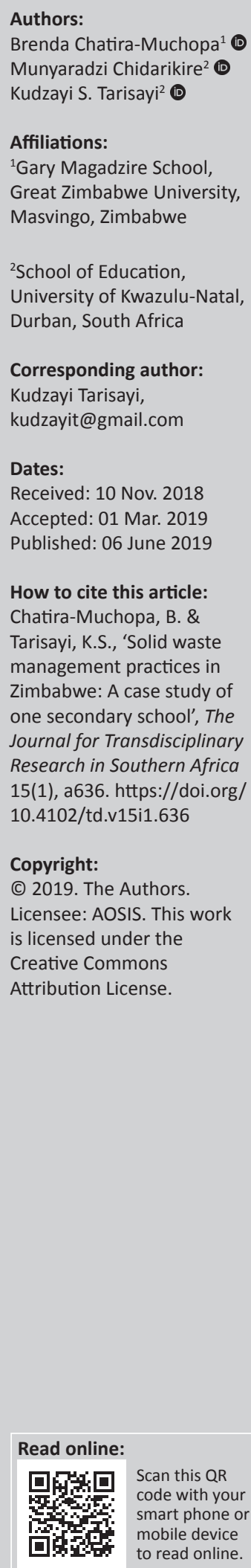

The discourse on waste management in general and solid waste management in particular has captured the interest of many scholars. Although there is a plethora of literature on the solid waste management phenomenon globally, there is an apparent dearth of literature on solid waste management in schools in Zimbabwe. This study explored the solid waste management practices at a secondary school in Masvingo. The researchers adopted a descriptive survey research design. Data were generated from 110 learners and 3 teachers using questionnaires and interviews. The researchers also utilised observations. Findings from the study revealed that solid waste generated by the school included paper, plastics, furniture, food, vegetables, stationery and cans. In addition, the researchers noted that the school used standard bins, cardboard boxes, plastic bags, old desks and open dumping as solid waste receptacles. The researcher also established that the main solid waste disposal system at the school was open dumping. Other solid waste disposal systems identified in this study were incineration, landfills and composting. Based on the research findings, the researcher recommends waste sorting and use of durable, standard and formal receptacles.

Keywords: Solid waste; solid waste management practices; secondary school; Masvingo; Zimbabwe.

\section{Introduction}

A plethora of studies have been carried on waste management around the world (Ana et al. 2011; Jerie 2006; Paya 2016; Yukalang, Clarke \& Ross 2018).

Waste can be classified in a multiplicity of ways. Generally, waste can be classified as liquid waste, solid rubbish, organic waste, recyclable rubbish and hazardous waste. Another narrative in waste management classifies waste as industrial and domestic waste (Links 2006). In addition, the legal instrument guiding waste disposal in Zimbabwe, the Environmental Management Act (EMA), Chapter 20:27, Section 72 (1), identifies the following categories of waste: hazardous waste, corrosive waste, flammable waste, toxic waste and radioactive waste. This article focuses on domestic solid waste generated at a school. In addition, the domestic waste generated at the school is of the non-sewage fraction. Globally, less developed countries are facing a high level of pollution, partly because of a lack of adequate solid waste disposal facilities (Ana et al. 2011). The most common types of waste generated in schools in Zimbabwe include paper, plastics, cans, food waste, aluminium foils, airtime voucher cards and stationery items like pencils and sharpeners (ChatiraMuchopa 2015).

In the Zimbabwean context, a number of studies on solid waste management have been carried out, arriving at varying conclusions. Nyanzou (2014) focused on solid waste management in high-density suburbs in Harare.

Jerie and Tevera (2014) profiled the composition of solid waste generated in the informal sector of Gweru.

In another study, Jerie (2006) pursues a comparison of environmental problems in domestic waste management in Gweru and Kwekwe. In addition, Mafume et al. (2016) interrogated the challenges of solid waste management in high-density suburb in Sakubva. According to a study by Van Niekerk (2014), there is empirical evidence globally, establishing that there is poor waste management in schools. However, it can be noted that there is an apparent dearth in the literature on solid waste management in schools in Zimbabwe. 


\section{Legislation on solid waste management in Zimbabwe}

There are several pieces of legislation in place pertaining to litter and waste management. Solid waste management in Zimbabwe is guided by the EMA, Chapter 20:27. Section 70 (1) of the EMA Act which stipulates that 'No person shall discharge or dispose any waste in a manner that causes environmental pollution or ill health to any person'. Thus, it follows that according to the EMA Act, any person whose activities generate waste is mandated to use measures to minimise the waste through treatment, reclamation and recycling, among others. In addition, Section 83 (1) of the EMA Act prohibits littering by stating:

No person shall discard, dump or leave any litter on any land or water surface, street, road or site in or at any place except in a container provided for that purpose or at a place which has been specially designated, indicated, provided or set apart for such purpose (EMA Act, Chapter 20:27).

In addition, the Urban Councils Act, Chapter 29:15, designates to urban local authorities the responsibility to provide solid waste collection, transportation and disposal services in areas under their jurisdiction. The Urban Councils Act and $E M A$ Act are some of the legislation that has been enforced in Zimbabwe, which provides a framework for solid waste management. Therefore, it can be argued that there is a legal framework on solid waste management in Zimbabwe. Despite the supportive legislation in Zimbabwe, the Environmental Management Agency (2014) reports that solid waste management in schools is still lagging behind. In addition, a study by Mandevere (2016) in Harare established that solid waste management problems are more pronounced at schools in urban areas. Therefore, it was imperative that another study be carried out in Masvingo to explore the adherence of schools to the legal framework. The participating school was selected because of its location close to the Central Business District.

\section{Research methods}

This study on the solid waste management practices used a descriptive survey. Orodho (2012) avers that a descriptive survey is a method of collecting information by interviewing or administering a questionnaire to a sample of individuals. In addition, a descriptive survey research design is a method of investigation which attempts to describe and interpret what exists at present in the form of conditions, practices, process, trends, effects, contribution and beliefs (Kulbir 2002). One school was purposively sampled by the researchers. The school was located in an urban area in Masvingo District, Zimbabwe. The sample for the study was composed of 110 learners and three teachers at the participating school. The demographic data for the learners who participated in this study are captured in Figure 1.

Figure 1 shows that there were 60 girls and 50 boys in this study. Age distribution of the learners was as follows: 29 learners (26\%) were aged 13 years and below; 25 learners (23\%) were aged between 14 and 15 years; 32 learners (29\%)

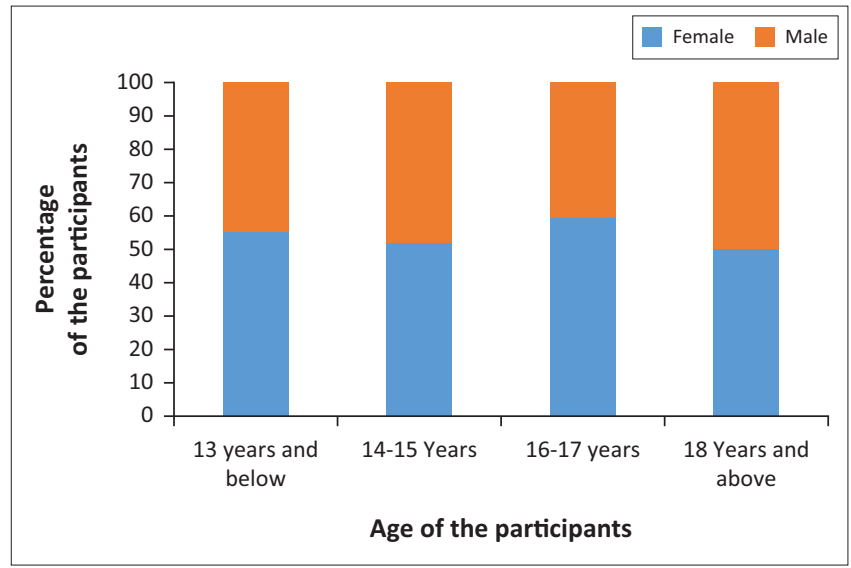

FIGURE 1: Demographic data of the learners.

were aged between 16 and 17 years and 24 learners (22\%) were aged 18 years and above. Thus, there was an even distribution in both gender and age. Among the teachers, there were two female participants and one male participant. Data were generated through 100 self-administered questionnaires which were distributed with the help of the teachers at the school. In addition, data were also generated through 13 interviews (10 learners and 3 teachers) and observations. Trustworthiness of the data was ensured through triangulation of both data sources (learners and teachers) and data generating methods (questionnaires, interviews and observations).

\section{Ethical consideration}

Gatekeepers permission was obtained from the Ministry of Primary and Secondary Education, as well as ethical clearance from Great Zimbabwe University

\section{Results}

The results from this study are presented as themes that emerged in the analysis of findings from the questionnaires, interviews and observations. The following major themes emerged: characteristics of solid waste, types of receptacles and average carrying capacity, waste disposal systems and preference of waste disposal.

\section{Characteristics of solid waste}

This section presents findings on the characteristics of solid waste generated at the school that participated in this study. The data were generated from the researchers' observation. The solid waste was sorted into the following categories: paper, plastics, food, stationery, cans, vegetation, furniture and airtime. Each category of waste was then weighed and the researchers tabulated the findings according to the source of the solid waste. The solid waste sources at the school were kitchen, hostel, grounds, classes, laboratories, workshops, administration block and agriculture.

Table 1 reveals the solid waste characteristics at the school that participated in this study. The school kitchen bin was composed of $61 \%$ food waste, $20 \%$ cans and $10 \%$ stationery. 
Waste from classes was composed of $60 \%$ paper, $20 \%$ plastic and $10 \%$ cans. However, waste from the administration was $50.5 \%$ paper, $12 \%$ plastics and $10 \%$ furniture. In addition, the study revealed that the waste had the following characteristics: $26 \%$ paper, $16.5 \%$ plastics, $16 \%$ furniture, $12 \%$ food, $10 \%$ vegetables, $8.5 \%$ stationery and $8 \%$ cans. The study established that the school's main sources of waste were the kitchen, classes and administration in chronological order. The waste at the school was mainly composed of paper, plastics and furniture. The interpretation of the findings indicates that the main type of solid waste at the school was paper. In addition, the results suggest that there is reliance on paper at the school that participated in this study. These findings feed into the narrative by Ana et al. (2011) that less developed countries are struggling with waste management. In addition, we argue that generating paper waste is still evident in schools in less developed countries that are yet to embrace Information Communication and Technology. Thus, these findings on paper being the main solid waste at schools concur with findings by Hoornweg and Laura (1999). Furthermore, it was noted that furniture was another major solid waste at the school. This suggests that the school instead of maintaining and repairing damaged furniture opted to dispose it as solid waste.

\section{Types of receptacles and average carrying capacity}

The researchers elicited data on the type of receptacles at the school through questionnaires, interviews and observations. The learners were asked to identify the receptacles that were available at the school, and this data was triangulated through the use of interviews and observations. The findings are presented in Table 2 .

Table 2 shows the types of receptacles identified in this study. The study identified the following receptacles used in solid waste management at the school: cardboard box, old desks, plastic bag, small metal bin, standard bin and open dumping. The study established that solid waste management at the school was not standardised as revealed by the different types of receptacles. In addition, it was also noted from this study that there was no waste sorting, as all solid waste was disposed in the same receptacle. The findings indicated that the main receptacles utilised at the school were cardboard boxes. The main reason being that cardboard boxes were readily available at the school as stationery, sports equipment and foodstuff for the school kitchen are supplied in cardboard boxes. Hence, instead of disposing of the cardboard boxes, they are used for the collection of solid waste around the school. Therefore, we argue that there is a form of recycling of waste as the cardboard boxes are reused within the school in waste management. However, it was also established from this study that the school was relying on traditional waste management in the form of open dumping. This finding indicates that the school is in actual contravention of Section 83 which prohibits littering. Resultantly, the findings of this study confirm the findings by the Environmental Management Agency (2014) that schools in Zimbabwe are struggling with solid waste management. In addition, findings indicated that there is no waste sorting at the school that participated in this study. Therefore, an essential component of waste management is that waste sorting is not being practised at the school. Ndum (2013) opines that waste sorting is essential in solid waste management.

\section{Waste disposal systems}

This section presents findings on the waste disposal systems adopted at the school that participated in this study. The data were generated from questionnaires, interviews and observations. The researchers utilised pictures to buttress findings, as shown in Table 3.

TABLE 1: Characteristics of solid waste.

\begin{tabular}{|c|c|c|c|c|c|c|c|c|c|}
\hline \multirow[t]{2}{*}{ Type } & \multicolumn{8}{|c|}{ Source in $\mathrm{kg}(\%)$} & \multirow[t]{2}{*}{ Average } \\
\hline & Kitchen & Hostels & Grounds & Classes & Laboratories & Workshops & Administration block & Agriculture & \\
\hline Paper & 3.0 & 20.0 & 30.0 & 60.0 & 20.0 & 20.0 & 50.5 & 5.0 & 26.0625 \\
\hline Plastics & 3.0 & 6.0 & 20.0 & 20.0 & 18.0 & 15.0 & 12.0 & 370 & 16.3750 \\
\hline Food & 61.0 & 20.0 & 5.0 & 5.0 & 0.5 & 0.5 & 5.0 & 0.5 & 12.1875 \\
\hline Stationery & 10.0 & 20.0 & 0.5 & 0.5 & 10.0 & 5.0 & 15.0 & 7.0 & 8.5000 \\
\hline Cans & 20.0 & 10.5 & 10.0 & 10.0 & 0.5 & 9.0 & 2.0 & 4.0 & 8.2500 \\
\hline Vegetation & 2.0 & 0.5 & 30.0 & 3.0 & 0.5 & 0.5 & 0.5 & 45.0 & 10.2500 \\
\hline Furniture & 0.0 & 20.0 & 3.5 & 0.1 & 50.0 & 48.0 & 10.0 & 0.5 & 16.5125 \\
\hline Airtime & 1.0 & 3.0 & 1.0 & 1.4 & 0.5 & 2.0 & 5.0 & 1.0 & 1.8625 \\
\hline Total & 100 & 100 & 100 & 100 & 100 & 100 & 100 & 100 & 100 \\
\hline
\end{tabular}

TABLE 2: Types of receptacles and average carrying capacity.

\begin{tabular}{|c|c|c|c|c|c|c|c|c|c|c|}
\hline \multirow[t]{2}{*}{ Receptacle } & \multicolumn{8}{|c|}{ Source and measured weight } & \multirow[t]{2}{*}{ Total } & \multirow[t]{2}{*}{ Average } \\
\hline & Kitchen & Hostels & Grounds & Classes & Laboratories & Workshops & Administration block & Agriculture & & \\
\hline Cardboard box & 25 & 10 & 0 & 20 & 10 & 20 & 25 & 0 & 110 & 13.75 \\
\hline Old desks & 0 & 0 & 0 & 10 & 0 & 10 & 20 & 0 & 30 & 3.75 \\
\hline Plastic bag & 15 & 10 & 0 & 1 & 10 & 0 & 3 & 20 & 59 & 7.313 \\
\hline Small metal bin & 0 & 10 & 0 & 9 & 10 & 5 & 3 & 0 & 37 & 4.563 \\
\hline Standard bin & 60 & 60 & 60 & 60 & 60 & 60 & 60 & 60 & 480 & 60 \\
\hline Open dumping & 0 & 10 & 40 & 0 & 10 & 5 & 20 & 20 & 85 & 10.63 \\
\hline Total & 100 & 100 & 100 & 100 & 100 & 100 & 100 & 100 & 800 & 100 \\
\hline
\end{tabular}


TABLE 3: Waste disposal systems.

\begin{tabular}{lcccc}
\hline System & $\begin{array}{c}\text { Learners } \\
\text { response }(\boldsymbol{f})\end{array}$ & $\begin{array}{c}\text { Teachers } \\
\text { response }(\boldsymbol{f})\end{array}$ & Totals $(\boldsymbol{f})$ & Average $(\boldsymbol{x})$ \\
\hline Open dumps & 110 & 3 & 113 & 67 \\
Composting & 70 & 0 & 70 & 35 \\
Land fills & 60 & 0 & 60 & 30 \\
Incineration & 70 & 2 & 72 & 36 \\
\hline
\end{tabular}

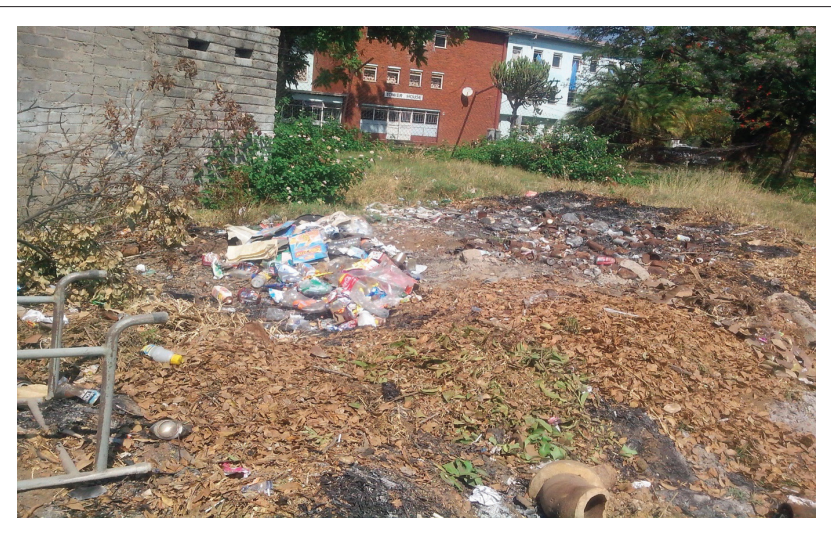

FIGURE 2: Open dump at the school.

Table 3 indicates that $67 \%$ revealed that solid waste at the school was disposed using open dumps, 35\% indicated the use of composting, 30\% revealed landfills and 36\% stated the use of incineration.

The findings captured in Table 3 are buttressed by Figure 2, showing an open dump. The picture aptly reveals an open dump where waste has been partially burnt. In addition, the solid waste in the picture includes furniture, ceramic, cans and plastic containers, among others. Thus, it can be argued from this study that the main solid waste disposal at the school was open dumping. This finding concurs with findings by Maluluke (2014), who reported that the main waste disposal system in Polokwane was open dumping. Open dumping is a cheaper option in developing countries despite its limitations and threats to sustainable development. In addition, Khan and Farooqi (2012) argue that if solid waste is not collected by the responsible authorities, residents resort to illegal dumping in open areas and drains.

\section{Preference of waste disposal}

The respondents were asked to indicate their preferred waste disposal system and their responses are captured in this section. All the respondents were unanimous in their preference for burning and refuse collection by council as waste disposal systems. There was consensus among learners and teachers that the preferred waste disposal methods were burning and refusing collection by council. It was evident that the participants were oblivious of the fact that burning solid waste leads to air pollution. In addition, the obvious fact that the school is located close to the Central Business District, as well as a residential area did not deter them from suggesting that they preferred burning solid waste. Figure 3 shows solid waste being burnt at the school.

Consequently, we argue that there was a preference for traditional waste disposal methods. As revealed earlier, the

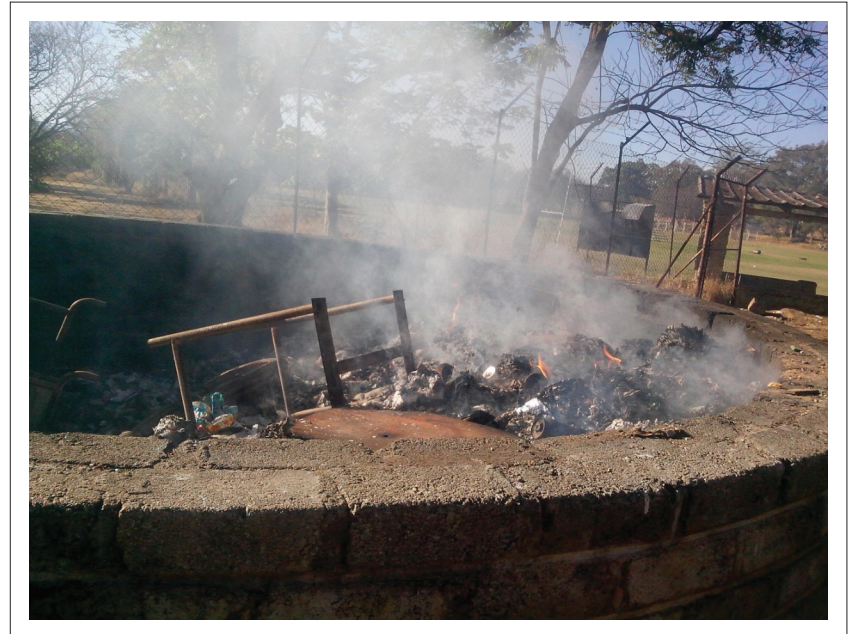

FIGURE 3: Burning of solid waste at the school.

bulk of the solid waste at the school was apparently recyclable. Thus, it can, therefore, be reasoned that the participants in this study seemed to be oblivious of recycling as a waste disposal method. The characteristics of the waste generated at the school indicated that paper and furniture were the main solid waste. Given such characteristics of the solid waste, recycling would have been a preferred method of waste disposal. Hence, we agree with Mandevere (2016) that waste disposal in Zimbabwe is still hinged on traditional methods and recycling is yet to be integrated in waste management. The researchers further confirmed findings by Mafume et al. (2016) that recycling strategies were noneexistent in Sakubva residential area in Zimbabwe. Resultantly, we further argue that there is a need for the adoption of recycling strategies instead of relying on traditional waste disposal systems.

\section{Conclusion}

The researchers conclude that the major solid waste at the school were paper, plastics, furniture, food, vegetables, stationery and cans. Despite the strides made in the use of paperless communication to Information Communication and Technology integration, the use of paper and paper communication is still prevalent at the school. Consequently, paper is the main solid waste at the school that participated in this study. In addition, the researchers conclude that there was no waste sorting at the school. All the solid waste was disposed of in the same receptacle. From the research findings, the researchers further conclude that the school did not use durable, standard and formal receptacles. The study established that the school used standard bins, cardboard boxes, plastic bags, old desks and open dumping as solid waste receptacles. The researchers also conclude that the main solid waste disposal system at the school was open dumping. Other solid waste disposal systems identified in this study are incineration, landfills and composting.

\section{Recommendations}

Based on the research findings and conclusions presented above, the researchers recommend waste sorting. The researchers 
further recommend the use of durable, standard and formal receptacles at the school. From the findings of this study, it is further recommended that school administrators and teachers be trained in proper solid waste disposal systems such as waste sorting and recycling.

\section{Acknowledgements Competing interests}

The authors declare that they have no financial or personal relationships that may have inappropriately influenced them in writing this article. The authors are solely responsible for the information, opinions and views presented in this article.

\section{Author's contributions}

B.C-M. designed the research instruments and generated the data. M.C generated the data and analysed the data. K.S.T. did the literature review and analysed the data. All authors participated in the presentation and editing of the article.

\section{References}

Ana, G.R.E.E., Oloruntoba, E.O., Shendell, D., Elemile, O.O., Benjamin, O.R. \& Sridhar, M.K.C., 2011, 'Solid waste management problems in secondary schools in Ibadan, Nigeria', Journal of Environmental Health 74(2), 24-29.

Chatira-Muchopa, B., 2015, 'Analysis of solid waste management practices in secondary schools: A case of Victoria and Mucheke High Schools, Masvingo, Zimbabwe', Unpublished Master's thesis, Midlands State University, Gweru.

Environmental Management Act Chapter 20:27, Parliament of Zimbabwe

Environmental Management Agency, 2014, Sustainable waste management programmes, viewed 02 July 2018, from https://www.ema.co.zw/index.php/140sustainable-waste-management-programmes.html.
Hoornweg, D. \& Laura, T., 1999, What a waste: Solid waste management in Asia, Urban and local government working paper series; No. UWP 1, The World Bank, Washington, DC, viewed 02 July 2018, from http://documents.worldbank.org/cur
694561468770664233/What-a-waste-solid-waste-management-in-Asia.

Jerie, S., 2006, 'Analysis of institutional solid waste management in Gweru Zimbabwe', Eastern Africa Social Science Research Review 22(1), 103-125. https://doi. org/10.1353/eas.2006.0004

Jerie, S. \& Tevera, D., 2014, 'Solid waste management practices in the informal sector of Gweru, Zimbabwe', Journal of Waste Management 2014, Article ID 148248 , 1-7. http://dx.doi.org/10.1155/2014/148248

Khan, S. \& Farooqi, I.H., 2012, 'Prioritising municipal solid waste management factors in India using fuzzy analytic hierarchy process', International Journal of Environment and Waste Management 10(4), 423-440. https://doi.org/10.1504/ IJEWM.2012.049821

Kulbir, S.S., 2002, Methodology of research in education, Sterling Publishers Private Limited, Bangalore.

Links, J.M., 2006, Municipal, industrial and hazardous waste, Environmental Health, Lecture 15, Johns Hopkins University, Baltimore, MD.

Maluluke, P.H., 2014, 'A review of solid waste management practices in Polokwane City', Unpublished Master's thesis, University of South Africa, Pretoria.

Mandevere, B., 2016, 'An investigation into the effectiveness of household solid waste management strategies in Harare, Zimbabwe', Unpublished Master's thesis, UNISA.

Ndum, A.E., 2013, 'Bottom-up approach to sustainable solid waste management in African countries', Unpublished PhD thesis, Brandenburg University of Technology, Cottbus.

Nyanzou, P., 2014, 'Analysis of solid waste management practices in high density suburbs: A case of Budiriro 3, Harare', Unpublished dissertation, Midlands State University.

Mafume, P.N., Zendera, W., Mutetwa, M. \& Musimbo, N., 2016, 'Challenges of solid waste management in Zimbabwe: A case study of Sakubva high density suburb', Journal of Environment and Waste Management 3(2), 142-155.

Orodho, J.A., 2012, Techniques of writing research proposals and reports in education and social sciences, Kanezja Publisher, Maseno, Kenya.

Paya, C., 2016, 'An integrated system of waste management in a developing country case study: Santiago de Cali-Colombia', Unpublished Master's thesis, University of Waterloo, Ontario.

Urban Councils Act, Chapter 29:15. Parliament of Zimbabwe.

Van Niekerk, I.M., 2014, 'Waste management behaviour: A case study of schoo children in Mpumalanga, South Africa', Unpublished Master's thesis, North-West University, Potchefstroom.

Yukalang, N., Clarke, B. \& Ross, K., 2018, 'Solid waste management solutions for a rapidly urbanizing area in Thailand: Recommendations based on stakeholders input', International Journal of Environmental Research and Public Health 15(7), 1-23. https://doi.org/3390/ijerph15071302 